\title{
Nik Trontelj
}

\section{Aleš Ušeničnik (1868-1952): profesor na Teološki fakulteti v Ljubljani}

\section{Aleš Ušeničnik (1868-1952): Professor at the Faculty of Theology in Ljubljana}

Povఇetek: Aleš Ušeničnik je bil učitelj filozofije na Teološki fakulteti v Ljubljani od njene ustanovitve do konca druge svetovne vojne. Pred ustanovitvijo Teološke fakultete je že od leta 1897 poučeval teologijo in filozofijo na Škofijskem bogoslovnem učilišču v Ljubljani. Po koncu prve svetovne vojne je sodeloval pri ustanovitvi Univerze v Ljubljani in v njenem okviru tudi Teološke fakultete. Leta 1919 je bil med prvimi učitelji, ki jih je kralj imenoval na položaj na Teološki fakulteti. Do upokojitve v letu 1938 je na Teološki fakulteti in Univerzi poleg učiteljskega dela večkrat opravljal tudi vodstvene službe. Z dolgoletnim učiteljskim delom in pomembnimi upravnimi službami se je pomembno zapisal v zgodovino slovenskega visokega šolstva in ljubljanske univerze. Prispevek je razdeljen na dva dela: najprej predstavljamo Ušeničnikovo izobraževanje in nato poučevanje na bogoslovnem učilišču. V drugem delu razprave pa obravnavamo njegovo delovanje na Teološki fakulteti: okoliščine njegovega imenovanja in učiteljsko delo. Pri predstavitvi učiteljskega dela opisujemo tudi vsebinsko zasnovo filozofskega seminarja in predavanj iz filozofije.

Ključne besede: Aleš Ušeničnik, Teološka fakulteta, Univerza v Ljubljani, krščanska filozofija, novosholastika

Abstract: Aleš Ušeničnik was a professor of philosophy at the Faculty of Theology in Ljubljana from its founding to the end of the Second World War. Since 1897 and prior to the founding of the Faculty of Theology, he had been teaching theological and philosophical subjects at the diocesan seminary college in Ljubljana. He participated in efforts for the establishment of the Faculty of Theology and the University of Ljubljana after the First World War. He was among the first professors who were appointed to the Faculty of Theology by the king in 1919. Before his retirement in 1938, he had also been serving in various leadership positions at the Faculty of Theology and University. With many years of teaching and leadership work, he left a significant mark in the development of Slovene higher education and the University of Ljubljana as its prominent contributor. This article is divided into two parts. The first part discusses 
Ušeničnik's education and his teaching years at the diocesan seminary college. The focus in the second part of the article is on his work at the Faculty of Theology, including the circumstances of his appointment and professorship. A special emphasis is given to the presentation of a subject matter of philosophical seminars and lectures in philosophy.

Key words: Aleš Ušeničnik, Faculty of Theology, University of Ljubljana, Christian philosophy, Neo-scholasticism

\section{Uvod}

Jubilej stoletnice delovanja Univerze $v$ Ljubljani in njene članice Teološke fakultete nam ponuja priložnost, da se s posebno hvaležnostjo spominjamo zaslužnih posameznikov, ki so s svojim znanjem in strokovno usposobljenostjo omogočili ustanovitev in uspešen začetek delovanja slovenske univerze v Ljubljani. Eden izmed njih je bil tudi bogoslovni profesor dr. Aleš Ušeničnik (1868-1952), vrhunsko izobraženi učenjak in tedaj že dolgoletni predavatelj na Bogoslovnem učilišču v Ljubljani. $\vee$ času priprav na ustanovitev univerzitetnega šolstva $v$ Ljubljani je sodeloval pri delu Vseučiliške komisije in kot član teološke podkomisije organiziral ustanovitev univerzitetne teološke fakultete. Ušeničnik je bil v skupini prvih učiteljev ljubljanske univerze, ki so bili za profesorje na naši univerzi imenovani 31. avgusta $1919 \mathrm{~s}$ kraljevim ukazom. Bil je tudi eden izmed prvih treh teologov, ki so bili istega dne postavljeni v službo na Teološki fakulteti; poleg Aleša Ušeničnika sta bila imenovana dr. Franc Ušeničnik in dr. Janez Zore (Miklavčič in Smolik 1969, 568). Ušeničnik je na fakulteti deloval pri stolici za krščansko filozofijo. $V$ našem prispevku bomo na podlagi virov osvetlili njegove stopnje izobraževanja in poučevanja teoloških predmetov na bogoslovnem učilišču v Ljubljani. Drugi del razprave pa bo namenjen obravnavi njegovega delovanja na Teološki fakulteti. Pri tem bomo najprej predstavili okoliščine Ušeničnikovega imenovanja in njegovo učiteljsko delo. Zatem bomo posebno pozornost namenili vsebinski predstavitvi filozofskega seminarja in predavanj iz filozofije, ki je bila njegova glavna študijska disciplina.

\section{Ušeničnikova izobrazba in učiteljsko delovanje na bogoslovnem učilišču v Ljubljani}

Na podlagi pregleda uradnih listin bomo najprej predstavili višje stopnje Ušeničnikovega izobraževanja; gimnazijsko izobrazbo v domovini ter študij teologije in filozofije na papeški univerzi Gregoriana v Rimu. Ušeničnik se je po končani osnovni šoli, ki jo je obiskoval v domačih Poljanah in v Škofji Loki, zaradi velike nadarjenosti vpisal na osemletno Cesarsko-kraljevo gimnazijo v Ljubljani. V gimnazijskih letih (1880-88) je bival v dijaškem semenišču, imenovanem Alojzijevišče, kjer se je oblikoval tako intelektualno kot tudi duhovno; ob zaključku šolanja se je odločil za duhovniški poklic. 
Ušeničnikovo maturitetno spričevalo iz leta 1888 pričuje o izvrstnem dijaku, ki je maturo opravil z odličnim uspehom. ${ }^{1}$ Gimnazijsko izobraževanje je na Cesarsko-kraljevi gimnaziji v Ljubljani začel v šolskem letu 1880/81 in svoje osemletno šolanje zaključil z maturo v šolskem letu 1887/88. Na podlagi opravljenega maturitetnega izpita pred izpitno komisijo je 20. julija 1888 prejel spričevalo. Večino šolskih predmetov je opravil z odličnim uspehom. Z oceno »odličnou je opravil naslednje predmete: verouk, latinski jezik, grški jezik, nemški jezik, slovenski jezik, zgodovina in geografija, fizika, prirodoslovje, filozofska propedevtika. Z oceno "pohvalnou je zaključil matematiko in italijanski jezik, prav tako so s pohvalnim uspehom ovrednotili njegovo vedenje. Uradno spričevalo se zaključuje s končno ugotovitvijo: „Ker je torej eksaminand zadostil zakonitim zahtevam z odličnim uspehom (mit Auszeichnung), se mu da ta svedočba o zrelosti za univerzitetne študije«. Na listini z dne 20. julija 1888 sta podpisana cesarsko-kraljevi deželni šolski nadzornik in cesarsko-kraljevi ravnatelj (ZAMU IV - 69, Maturitetna svedočba, 1888).

Kot že omenjeno zgoraj, je Ušeničnik po zaključenem gimnazijskem izobraževanju vstopil v bogoslovje. Tedanji ljubljanski škof Jakob Missia ga je poslal na študij v Rim, kjer mu je uredil brezplačno bivanje v zavodu Germanik - spadal je namreč med najbolj nadarjene duhovniške kandidate (Bobič 2011, 162). Aleš Ušeničnik se je tako uvrstil v vrsto ljubljanskih bogoslovcev, ki so ob koncu 19. stoletja študirali v Rimu. Med njimi je bil tudi Alešev starejši brat Franc Ušeničnik, kasnejši učitelj na Teološki fakulteti v Ljubljani in njen prvi dekan. Ušeničnik je v rimskih študijskih letih dobro spoznal sholastično misel in filozofijo sv. Tomaža Akvinskega.

Na univerzi Gregoriana je dosegel doktorat iz filozofije. Ušeničnikov prevod uradne latinske doktorske diplome iz leta 1926 dokazuje, da je prvi doktorat dosegel na zagovoru pred izpitno komisijo doktorjev filozofije 26. junija 1891 (ZAMU IV - 69, Doktorska diploma iz filozofije, 1891). Na zastavljena vprašanja je Ušeničnik odgovoril ustrezno, zato so vsi člani komisije uspešno opravljen zagovor potrdili in mu podelili doktorat iz filozofije. Doktorska listina se sklene takole:

»Ker je g. Aleksij Ušeničnik dajal več let dokaze lepega vedenja in krščanske kreposti in ker je s pismeno disertacijo in posebnim izpitom dokazal svoje znanje filozofskih znanosti, so vsi tega mnenja, naj se mu radi krepostnosti in znanja podeli doktorat filozofije. G. Aleksij Ušeničnik je na to izpovedal vero in se slovesno zavzel, da bo vedno in povsod branil nauke katoliške Cerkve. Mi pa smo s papeškim pooblaščenjem /.../g. Aleksija Ušeničnika razglasili za doktorja filozofije in mu dali oblast, da rabi vse pravice, oblasti, insignije in privilegije filozofskega doktorata. Opominjamo pa veleučenega g. Aleksija Ušeničnika, da pravice, učiti kjerkoli filozofijo, ki mu sedaj pristoji, ne rabi, kolikor mogoče, razen z dovoljenjem pristojne oblasti. Znanje pa, ki si ga je pridobil, naj modro in vrlo rabi v obrambo tistih oblasti, ki jih je Vsemogočni postavil v Cerkvi in državi! V Rimu, 10. avgusta 1891.«

1 Gre za kasnejši lastnoročni Ušeničnikov prepis maturitetnega spričevala, ki ga je za službene potrebe kot uslužbenec Univerze iz nemščine tudi prevedel. Podobno je iz izvirnih jezikov prevedel mnoge svoje zgodnje uradne dokumente, ki jih hrani ZAMU in jih navajamo v prispevku. 
Dr. Ušeničnik je ostal v Rimu še naslednja 4 leta. 28. oktobra 1894 je v Germaniku prejel mašniško posvečenje in postal duhovnik (Pirc 1986, 22). 1. junija 1895 je na Gregoriani uspešno opravil zagovor pred doktorji profesorji teološke fakultete, ki so mu podelili doktorat iz teologije. V arhivu Zgodovinskega arhiva in muzeja Univerze v Ljubljani (ZAMU) hranijo slovenski prevod Ušeničnikove doktorske diplome iz teologije (6. junij 1895), ki je bila izvirno izdana v latinščini, a jo je Ušeničnik kasneje kot uslužbenec Univerze v Ljubljani za potrebe svojega službenega lista lastnoročno prepisal v slovenskem prevodu (ZAMU IV - 69, Doktorska diploma iz bogoslovja, 1895). Uradno besedilo je podobno besedilu doktorske diplome iz filozofije, ki ga navajamo zgoraj.

Po zaključenem študiju v Rimu se je Ušeničnik poleti vrnil v domovino. Le en mesec po podelitvi doktorata iz teologije je bil mladi doktor postavljen na svoje prvo duhovniško delovno mesto. Ljubljanski škof Jakob Missia ga je 13. julija 1895 imenoval za kaplana v Stari Loki. Izdani dekret Ušeničnika že naziva kot »doktorja bogoslovja in modroslovja«. Besedilo pravi: "S tem dekretom, ki ga boste pokazali, čim nastopite službo, g. dekanu, Vas imenujemo za drugega kaplana v Stari Loki in Vas pooblaščamo za dušno pastirstvo v župnijski cerkvi sv. Jurija kakor tudi v drugih cerkvah naše škofije, če Vas bo s privoljenjem Vašega župnika kak drugi dušni pastir prosil pomoči« (ZAMU IV - 69, Imenovanje Aleša Ušeničnika na mesto kaplana v Stari Loki, 1895).

Ušeničnik je kaplansko službo v Stari Loki opravljal le dobro leto, nato pa je že prejel novo odločbo ljubljanskega knezoškofijskega ordinariata. 5. novembra 1896 je bil premeščen v ljubljansko stolno cerkev sv. Nikolaja, kjer je nastopil službo stolnega vikarja (ZAMU IV - 69, Imenovanje Aleša Ušeničnika na mesto stolnega vikarja v Ljubljani, 1896). Besedilo dokumenta je podobno dekretu o imenovanju v kaplansko službo v Stari Loki, ki ga navajamo zgoraj.

Verjetno je Ušeničnik prišel v Ljubljano zaradi načrta škofijskega ordinariata, da visoko izobraženi škofijski duhovnik nastopi učiteljsko službo na Bogoslovnem učilišču. Že po nekaj mesecih bivanja v Ljubljani je 24. marca 1897 namreč prejel novo uradno listino. Škof Missia, ki je bil Ušeničnika pred devetimi leti poslal na študij v Rim, ga je sedaj imenoval za nadomestnega profesorja Janeza Evangelista Kreka na bogoslovnem učilišču. Škof tako piše Alešu Ušeničniku, stolnemu vikarju v Ljubljani: "S tem dekretom Vas imenujemo za suplenta fundamentalne teologije in filozofije na škofijskem bogoslovnem učilišču v Ljubljani. Službo Vam je nastopiti 28. marca 1897. « (ZAMU IV - 69, Imenovanje Aleša Ušeničnika na mesto suplenta na škofijskem bogoslovnem učilišču v Ljubljani, 1897) Ušeničnik je tedaj nastopil učiteljsko službo, ki je njegovo nadaljnjo poklicno pot najbolj zaznamovala. Na bogoslovnem učilišču je poučeval do zadnjega leta svojega delovanja in ustanovitve Teološke fakultete v letu 1919.

Ušeničnik je na bogoslovnem učilišču tri leta poučeval kot suplent, nato pa ga je ljubljanski škof Anton Bonaventura Jeglič imenoval za rednega profesorja dogmatične teologije, ki jo je do tedaj poučeval Frančišek Lampe, a je ob koncu septembra 1900 nepričakovano umrl. Ušeničnik je tako zapolnil izpraznjeno mesto 
učitelja dogmatike. Dopis knezoškofijskega ordinariata v Ljubljani z dne 1. oktobra 1900, ki je bil naslovljen na stolnega vikarja, doktorja teologije in filozofije Aleša Ušeničnika, pravi takole:

„Vaše zgledno duhovniško življenje, Vaša temeljita bogoslovna izobrazba in spretnost za bogoslovna predavanja, katero ste že tudi dejansko pokazali, nas nagiba, da Vas imenujemo profesorja specijalne dogmatike na ljubljanskem bogoslovnem učilišču, trdno se nadejajoči, da bodete skušali, kakor doslej, tudi v tem svojem važnem poklicu z vso vnemo in vestnostjo delovati v čast božjo in blagor škofije. V to naj Vam dá Vsemogočni svoj blagoslov. V smislu cerkvenih določil Vam tudi naročamo, da pridete semkaj izpovedat katoliško vero. " (ZAMU IV - 69, Imenovanje Aleša Ušeničnika na mesto rednega profesorja na škofijskem bogoslovnem učilišču v Ljubljani, 1900)

Ušeničnik je od leta 1907 na ljubljanskem bogoslovnem učilišču poučeval tudi sociologijo, v katero se je za potrebe svojih predavanj temeljito poglobil. Leta 1910 je tako izdal obsežno delo Sociologija, ki ob Krekovi najslavnejši knjigi Socijalizem (1901) velja za temeljno delo v zgodovini slovenske sociološke vede. Ušeničnikovo sociološko študijo lahko uvrstimo med kvalitetnejša mednarodna dela na tem področju. Dr. Lampe je ob njenem izidu v svoji oceni zapisal, da lahko »dr. Ušeničnikovo knjigo stavimo med najboljše, kar se je napisalo o tej vedi«, saj je dr. Aleš Ušeničnik »tih in miren učenjak, ki nabira snov z bučelično pridnostjo in vsako trditev vestno pretehta in oceni njeno vrednost « (Lampe 1910, 283). Ušeničnik je sociologijo kasneje predaval tudi na Teološki fakulteti.

\section{Ušeničnikovo delovanje na Teološki fakulteti v Ljubljani}

\subsection{Imenovanje na profesorsko mesto na Teološki fakulteti}

Aleš Ušeničnik je od začetka deloval pri Vseučiliški komisiji, ki je organizirala ustanovitev ljubljanske univerze in spada med najzaslužnejše posameznike za začetek njenega delovanja v letu 1919. Bil je tudi član tričlanske teološke podkomisije za ustanovitev teološke fakultete in podkomisije za novo univerzitetno knjižnico (Miklavčič in Smolik 1969, 568). Teološka podkomisija je morala predlagati kandidate za osnovanje učiteljskega zbora bodoče teološke fakultete. Vsak učitelj Univerze v Ljubljani je moral pridobiti potrditev o svoji strokovni usposobljenosti od ene izmed že delujočih fakultet. Prvi teološki učiteljski kandidati z bogoslovne šole so tako za pridobitev potrdila zaprosili teološko fakulteto v Zagrebu, ki je v marcu 1919 izdala potrdilo za učiteljsko usposobljenost prvih treh učiteljev (Kolar 2009, 60). ${ }^{2}$ Akt o kvalifikaciji, ki ga hrani arhiv teološke fakultete v Zagrebu, priča, da je

2 Glede na poročilo teološke podkomisije pri Vseučiliški komisiji z dne 13. marca 1919 (Polec 1929, 229) lahko sklepamo, da so prvi trije predavatelji (A. Ušeničnik, F. Ušeničnik, J. Zore) prejeli izjavo zagrebške teološke fakultete o svoji strokovni usposobljenosti že pred 13. marcem. Izjava o kvalifikaciji, ki jo hrani 
bil Aleš Ušeničnik za univerzitetnega profesorja potrjen. Omenjeni dokument tako pravi: «Na podlagi predloženih »curricula vitae« in spisov izjavlja zagrebška bogoslovna fakulteta, da so gg. bogoslovni profesorji dr. Aleksij Ušeničnik, dr. Franjo Ušeničnik in dr. Ivan Zore znanstveno povsem kvalificirani za vseučiliške profesorje.« (AKBF, Strokovna kvalifikacija vseučiliških profesorjev, 1919)

Prvi trije potrjeni učitelji Teološke fakultete so bili potem predlagani še Vseučiliški komisiji (Polec 1929, 229). ${ }^{3}$ Brata Ušeničnik in Zore so bili nato 31. avgusta 1919 s kraljevim ukazom tudi uradno postavljeni v službo. Prestolonaslednik Aleksander je v uradnem dopisu, ki je ohranjen v kasnejšem prepisu, Ušeničnika imenoval za rednega profesorja z naslednjimi besedami: „Njegovo kraljevsko Visočanstvo Aleksandar naslednik prestola /.../ na predlog gospodina ministra prosvete blagovolio je ukazom svojim od današnjeg dana postaviti za redovnog profesora na teološkom fakultetu univerziteta u Ljubljani Dr. Aleksija Ušeničnika, bogoslovnog profesora u Ljubljani. U Beogradu 31. avgusta 1919 godine.« (ZAMU IV - 69, Prestolonaslednikovo imenovanje Aleša Ušeničnika na mesto rednega profesorja na Teološki fakulteti Univerze v Ljubljani, 1919)

\subsection{Profesura na Teološki fakulteti}

Ušeničnik je 1. septembra 1919 postal član učnega kolegija na Teološki fakulteti in zasedel stolico za krščansko filozofijo. Na Teološki fakulteti je ponovno začel predavati filozofijo, ki se je ločila od osnovnega bogoslovja (Polec 1929, 227; 478). Vsako študijsko leto je izvajal filozofski seminar ${ }^{4}$ in do leta 1933 predaval tudi sociologijo. Ušeničnik je na Teološki fakulteti honorarno predaval tudi še po svoji upokojitvi (1938), saj je do konca druge svetovne vojne izvajal predmet o »Summi« sv. Tomaža Akvinskega (Pirc 1986, 24; Miklavčič in Smolik 1969, 570).

Študijski predmeti, ki jih je na Teološki fakulteti predaval Ušeničnik, so bili uvrščeni v filozofsko-dogmatično skupino. Ušeničnik je bil nosilec predmetov s področja krščanske filozofije. Seznam strokovnih področij Teološke fakultete iz študijskega leta 1926/27 poleg krščanske filozofije navaja tudi druge predmete in njihove nosilce v filozofsko-dogmatični skupini: (primerjalno) veroslovje (Ehrlich), osnovno bogoslovje (Grivec), sistematična dogmatika (Fabijan), historična dogmatika (Lukman) (ATF, Stroke in nastavniki na Teološki fakulteti, l. 1926-27). Omenjena skupina se je šele po Ušeničnikovi upokojitvi v študijskem letu 1940/41 razdelila v ločeni skupini za filozofijo in dogmatiko, filozofski predmeti pa so bili uvrščeni v filozofsko skupino (ZAMU, Seznam predavanj na univerzi v Ljubljani 1932-1944).

Ušeničnik je že od svojih prvih učiteljskih let v bogoslovnem semenišču veljal za odličnega predavatelja, o čemer so kasneje pripovedovali njegovi študentje.

arhiv Teološke fakultete $v$ Zagrebu, datuma izdaje nima pripisanega, v literaturi pa se kot datum pojavlja 21. marec.

3 A. Ušeničnik, F. Ušeničnik in J. Zore so poročilu teološke podkomisije o ustanavljanju Teološke fakultete 13. marca 1919 priložili svoje strokovne življenjepise in izjavo zagrebške teološke fakultete o svoji strokovni usposobljenosti. Navedena letnica 1929 je v viru (Polec 1929, 229) le posledica tiskarske napake.

4 Dr. Ušeničnik filozofskega seminarja zaradi mnogih drugih delovnih obveznosti ni izvajal le $v$ študijskem letu 1922/23, ko je na Univerzi opravljal službo rektorja. 
Tudi na Teološki fakulteti je Ušeničnik s predavanji, ki so odsevala njegovo globoko osebnost, slušatelje navduševal (Strle 1968, 186; 189-90). Ušeničnikovo uspešno pedagoško delo na fakulteti mu je omogočilo, da je v državni službi napredoval. Kralj Aleksander je 24. oktobra 1926 na predlog Ministrstva za prosveto Ušeničnika imenoval za rednega profesorja na Teološki fakulteti s pravicami uradnika 2. skupine 1. kategorije. Pred imenovanjem je bil redni profesor 3. skupine 1. kategorije (ZAMU IV - 69, Kraljevo imenovanje Aleša Ušeničnika za rednega profesorja 2. skupine 1. kategorije, 1926). Ta odlok je vplival na višino Ušeničnikovih prejemkov, obenem pa je pomenil tudi priznanje njegovemu dotedanjemu učiteljskemu delu. Ušeničnik se je po skoraj dveh desetletjih delovanja na Teološki fakulteti uradno upokojil leta 1938 - službe na Univerzi v Ljubljani je bil uradno razrešen 7. marca 1938 (ZAMU IV - 69, Izpisek iz uslužbenskega lista dr. Aleša Ušeničnika, 8. marca 1938). V študijskem letu 1938/39 je tako študijske predmete s področja krščanske filozofije začel poučevati dr. Janez Janžekovič. Ušeničnikovo učiteljsko delo pri filozofiji, ki je bilo njegovo glavno strokovno področje, zasluži posebno pozornost, zato bomo v nadaljevanju vsebino in izvedbo njegovih predavanj pri filozofiji in filozofskem seminarju predstavili natančneje.

Pri orisu Ušeničnikovega delovanja na Teološki fakulteti Univerze v Ljubljani moramo omeniti še njegove vodstvene službe v upravi obeh ustanov. Aleš Ušeničnik je bil na Teološki fakulteti trikrat izvoljen za dekana. Dekanski mandat je trajal po eno študijsko leto. Ušeničnik je v presledkih dekanoval v letih 1920/21, $1926 / 27$ in 1932/33. V študijskem letu 1922/23 pa je bil rektor Univerze v Ljubljani (Kolar 2009, 70; Miklavčič in Smolik 1969, 569). Po izteku dekanskih mandatov je vedno opravljal še enoletno službo prodekana. Po letu rektorata je bil prorektor Univerze. Ušeničnik je bil kot redni profesor, dekan in rektor pogosto član različnih univerzitetnih upravnih organov.

\subsection{Predavanja iz filozofije}

Aleš Ušeničnik je na Teološki fakulteti filozofijo predaval vsa leta svojega delovanja, od prvega študijskega leta 1919/20, pa vse do 1937/38, ko se je upokojil. Tudi po upokojitvi je na Teološki fakulteti honorarno poučeval še nekaj let. Pri izvedbi filozofskih predmetov so mu občasno pomagali nekateri profesorji iz drugih študijskih skupin, ki so predavali različne predmete s področja filozofije. Od študijskega leta 1932/33 do 1935 je tako npr. veroslovec Lambert Ehrlich predaval teodicejo v luči (zgodovine) verstev, od študijskega leta 1935/36 do Ušeničnikove upokojitve pa izmenično kozmologijo in filozofijo religije. Predavatelj cerkvene zgodovine Josip Turk je predaval zgodovino filozofije, predavatelj moralne teologije Josip Ujčić pa etiko (ZAMU, Seznam predavanj na univerzi v Ljubljani 19321944; Juhant 1990, 46).

Pri predavanjih za filozofijo je Ušeničnik uporabljal svoja lastna skripta. Za predmet Uvod v filozofijo je že leta 1921 pripravil učbenik Spoznavno-kritični del, tri leta kasneje pa izdal še Metafizični del. Obe deli skupaj sestavljata zaokroženo celoto Uvod v filozofijo. Verjetno je pri predavanjih uporabljal tudi skripta Ontologija iz leta 1924, ki jih je dodal zbirki Uvod v filozofijo (Pirc 1986, 31). 
Uporaben vir za globlji vpogled v vsebino filozofskih študijskih predmetov v posameznih študijskih letih so letna poročila o učiteljskem delu. Ušeničnik je moral kot član profesorskega zbora ob zaključku letnega semestra dekanatu Teološke fakultete vsako leto oddati svoje poročilo. Poročila nudijo vpogled v vsebino študijskih predmetov in osvetljujejo pedagoško delo. V Arhivu Teološke fakultete in Nadškofijskem arhivu v Ljubljani hranijo skoraj vsa Ušeničnikova poročila iz obdobja njegovega delovanja na Teološki fakulteti. Ušeničnik je vsa poročila napisal lastnoročno in $v$ njih posredoval bistvene podatke o izvajanih predmetih, tako tudi o vsebinskih poudarkih, časovni izvedbi, številu slušateljev, izpitnih obveznostih ipd. V najstarejšem ohranjenem poročilu Ušeničnik predstavlja svoje delo v študijskem letu 1921/22 (ATF, Poročilo rednega profesorja dr. Aleša Ušeničnika za študijsko leto 1921/22, 19. junija 1922). Poročilo navajamo v celoti:

»Redni profesor dr. Aleš Ušeničnik je v štud. letu 1921/22 v zimskem in poletnem semestru predaval filozofijo po 6 ur na teden. Obdelal je noetiko in ontologijo. Rednih slušateljev je bilo v zimskem semestru 31, v poletnem 27 . $V$ zimskem semestru jih je 26 delalo kolokvijski izpit in sicer poprek $s$ prav dobrim uspehom. Za poletni semester se jih je oglasilo za kolokvijski izpit 25. V filozofskem seminarju je bilo zimski semester $17, \mathrm{v}$ poletnem 14 članov. Obravnavali smo posebej v zimskem semestru problem svobodne volje, v poletnem nauk o idejah. Poleg tega je isti profesor predaval po 1 uro na teden sociologijo. Rednih slušateljev je bilo zimski semester 53, poletni 51 . $V$ poletnem semestru je delalo 25 slušateljev kolokvijski izpit. V Ljubljani, 19. junija 1922. Dr. Aleš Ušeničnik.«

Podobno zasnovo imajo tudi poročila iz poznejših let. V poročilu za leto 1922/23 Ušeničnik pravi, da je oba semestra predaval metafiziko po 6 ur na teden. Obisk slušateljev naj bi bil »jako priden«. V tem študijskem letu je Ušeničnik opravljal službo rektorja, kar je navedel tudi v poročilu. Ušeničnik pravi: »Filozofskega seminarja to leto nisem vodil, ker sem bil preveč zaposlen z rektoratom « (ATF, Poročilo red. prof. filozofije na teološki fak. dr. Al. Ušeničnika za štud. I. 1922/23, 30. junija 1923). V študijskem letu 1926/27 je v obeh semestrih predaval posebno filozofijo, ıt.j. najvažnejša poglavja iz kozmologije, psihologije in teodiceje.$^{5}$ Pri sociologiji je obrav-

5 Upokojeni honorarni predavatelj dr. Aleš Ušeničnik je junija 1938 pripravil pregled vsebine predmetov, ki jih je predaval. Dekanat Teološke fakultete je vsebinske preglede vseh predmetov, ki so se predavali na fakulteti, poslal škofijskemu ordinariatu v Ljubljani. V Ušeničnikovem pregledu snovi so predstavljene tudi vsebine psihologije, kozmologije in teodiceje.

Ušeničnik je snov za psihologijo razdelil v dva dela. Pri empiričnem delu je obravnaval psihične pojave, zavest in podzavest, psihoanalizo in naslednje vsebine: o čutih, čustvih, spominu, nagonih, umu, hotenju, svobodni volji ipd. Drugi del psihologije je naslovil »o duši« in nasproti materializmu ter modernim teorijam dokazoval, da je človeška duša duhovna in je podstatni dej telesa. Sledila je kritika modernih teorij o razmerju med dušo in telesom, ki jih je spodbijal z naukom sv. Tomaža Akvinskega.

Pri kozmologiji je snov razdelil na štiri dele: a) o naravi in sestavi teles, o razsežnosti idr.; b) o živih bitjih, o bistvu in stopnjah življenja; c) o razvoju živih bitij (zlasti darvinizem); d) o svetu, o početku sveta, o smislu in koncu sveta idr.

Tudi predavanja iz teodiceje je razdelil na dva dela, ki ju je izvajal v dveh semestrih. Nekateri vsebinski poudarki prvega dela so bili: o božji spoznavnosti; dokazi za bivanje božje; kritika drugih poti do Boga, npr. teorija o »doživljanju«. V drugem delu je obravnaval božjo naravo z naslednjimi poudarki: Bog je 
naval načela socialne ekonomije z vidika krščanske etike (ATF, Poročilo prof. dr. Al. Ušeničnika v štud. I. 1926/27). V študijskem letu 1927/28 je predaval osnovno (občno) filozofijo, tj. kritiko in ontologijo (ATF, Poročilo dr. Al. Ušeničnika, red. prof. za krščansko filozofijo v štud. I. 1927/28, 21. junija 1928). Vsa omenjena področja je pri filozofskih predmetih obravnaval tudi v različnih drugih študijskih letih.

\subsection{Filozofski seminar}

Ušeničnik je na Teološki fakulteti redno izvajal seminar in študente uvajal v znanstveno delo. Pri seminarju je študente največkrat seznanjal z izbranimi poglavji iz Summe Tomaža Akvinskega. V študijskem letu 1921/22 je obravnaval problem svobodne volje in nauk o idejah (ATF, Poročilo rednega profesorja dr. Aleša Ušeničnika za študijsko leto 1921/22, 19. junija 1922). V letu 1927/28 so pri seminarju »čitali in tolmačili poglavja o spoznanju iz Summe Tomaža« in »obdelali prvi semester teorijo silogizma, v poletnem semestru pa teorijo preizkusili v disputacijah« (ATF, Poročilo dr. Al. Ušeničnika, red. prof. za krščansko filozofijo v štud. I. $1927 / 28,21$. junija 1928 ). Leta $1928 / 29$ so pri seminarju »čitali in predelavali Summo Tomaža Akv. in sicer 1 II prva poglavja iz etike« (ATF, Letno poročilo red. prof. dr. Ušeničnika Aleša o štud. I. 1928/29, 27. junija 1929). V letu 1929/30 so pri Tomaževi Summi obravnavali naslov De passionibus animae in naslednje vsebine: 1) problem o religioznem doživljanju; 2) razvoj Vebrove filozofije, kakor se kaže v prvem in drugem Uvodu z nasprotji, ki še niso izravnana. Pri vajah so obravnavali »strukturo skolastičnih disputacij in napravili ta in oni poizkus« (ATF, Poročilo o filozofskem seminarju teološke fakultete 1929/30, 1. junija 1930). V letu 1930/31 so obravnavali vsebino Tomaževe Summe o božjem spoznanju. Ušeničnik je zapisal še: „Poleg tega smo obravnavali podrobneje ta in oni filozofski problem iz predavanj « (ATF, Poročilo o filozofskem seminarju teološke fakultete 1930/31, 28. junija 1931). V študijskem letu 1937/38, ki je bilo Ušeničnikovo zadnje leto pred upokojitvijo, je v latinskem poročilu zapisal, da so pri seminarju kritično razpravljali o delu La Psychologie des foules (Psihologija množic) Gustava Le Bona iz leta 1895 (NŠAL, Seminarium philosophicum [dr. Ušeničnik Aleš], 6. junija 1938).

Ušeničnik se je za organizacijo vsakoletnega filozofskega seminarja temeljito pripravljal. Za potrebe filozofskega seminarja je prek Jugoslovanske knjigarne v Ljubljani vsa leta naročal strokovno literaturo s področja filozofije; ta literatura razodeva temeljno idejno usmeritev Ušeničnikovega dela pri seminarju. Seznami naročene literature vsebujejo večinoma tuja dela, in sicer je največ publikacij v nemškem in francoskem jeziku. ${ }^{6}$ Že bežen pogled na seznam literature razodeva

nujen, večen, neskončno popoln; Bog stvarnik - Bog oseba - Bog Sveti; božja previdnost in zlo na svetu idr. (NŠAL, Tvarina predelana iz filozofije [dr. Ušeničnik Aleš], 6. junija 1938).

6 Ušeničnik je v svojem uslužbenskem listu sam zabeležil podatek o znanju tujih jezikov. Najbolje je obvladal nemščino in latinščino. Po svojem mnenju je znal zadostno italijansko. Imel je bralno razumevanje drugih slovanskih jezikov, francoščine in deloma španščine ter grščine (ZAMU IV - 69, Izpisek iz uslužbenskega lista dr. Aleša Ušeničnika, 8. marca 1938). Verjetno je bil pri svojem opisu znanja tujih jezikov v uslužbenskem listu celo nekoliko skromen. Ušeničnik se je namreč odlikoval s prevajalskim delom in je obvladal latinščino, staro in novo grščino, italijanščino, nemščino, španščino, francoščino in angleščino, med slovanskimi jeziki pa ruščino in hrvaščino (Debeljak 2018, 38). 
njeno pretežno sholastično usmerjenost. Ušeničnik je kot izrazit predstavnik katoliške novotomistične prenove študente uvajal v sholastično filozofijo. To je posebej očitno pri temah seminarjev, ki jih navajamo zgoraj. Ušeničnik pa kot predstavnik novotomizma v svoji misli ni le posnemal starih Tomaževih naukov, ampak je s pomočjo tomističnega izročila pripravljal um za spoznanje novih resnic (Petkovšek 2008, 37; 49). Iz seznamov naročene literature lahko ugotovimo, da je bil Ušeničnik na tekočem s tedanjo novosholastično mislijo. Glede na sezname naročenih publikacij lahko literaturo razdelimo v tri skupine: znanstvene revije, dela iz zgodovine filozofije, sodobna dela.

Ušeničnik je vsa leta naročal letnike znanih tujih revij z novosholastično usmeritvijo: Revue Thomiste, Revue Neo-scolastique de philosophie, Divus Thomas in Philosophisches Jahrbuch (NŠAL, Filozofski seminar teološke fakultete v Ljubljani [račun], 13. novembra 1922; 16. junija 1924; 24. septembra 1928; 31 . oktobra 1928; 27. junija 1929; 25. aprila 1930 idr. [revije]). Izhajanje tovrstnih revij, ki so v katoliški filozofiji in teologiji utrjevala tomistična načela, je spodbudila papeževa okrožnica Aeterni Patris, ki jo je leta 1879 objavil papež Leon XIII. ${ }^{7}$

V drugi skupini naročenega knjižnega gradiva so nekatera dela zgodovinsko pomembnih filozofov. Ušeničnik je tako naročil tedaj povsem novi slovenski prevod O človeškem razumu (John Locke, 1924), drugi zvezek zgodnjega novoveškega klasičnega tomističnega dela Cursus philosophicus Thomisticus (Joannis de St. Thoma, znova izdano 1883), Kantova predavanja Sechzehn Vorlesungen gehalten an der Berliner Universität (Georg Simmel, prvič izdano 1904) ter pregledni deli Geschichte der Alten Philosophie (Hans Meyer, izdano 1925) in Aristoteles - Lexikon (Matthias Kappes, prvič izdano 1894). (NŠAL, Filozofski seminar teološke fakultete v Ljubljani [račun], 22. decembra 1924; 1. septembra 1931; 16. januarja 1925; 29. marca 1926 [zgodovina filozofije]).

V tretjo skupino uvrščamo novejša dela, ki jih je Ušeničnik naročal kmalu po njihovem izidu in dokazujejo njegovo seznanjenost s pomembnimi avtorji in njihovimi aktualnimi deli. V obdobju 1923-30 je tako naročil mnogo sodobnih del, ki so izšla prav v istem obdobju (ali pa malo pred 1923). Nobeno naročeno delo ni bilo starejše od nekaj let. Omenimo naj le nekaj primerov: Vom Umsturz der Werte (Max Scheler, 1919), System der Philosophie (Heinrich Rickert, 1921), Elemente zu einer Religionsphilosophie (Otto Gründler, 1922), Der proletarische Sozialismus (Werner Sombart, 1924), Katholisches und modernes Denken (August Messer, 1924), Das Arbeitsethos der Kirche nach Thomas von Aquin und Leo XIII (Johannes Haessle, 1924), Der Sinn der Geschichte (Nikolaj Berdjajev, 1925), Saint-Thomas d'Aquin (Edgar de Bruyne, 1928), Vom Dasein Gottes (Franz Brentano, 1929) (NŠAL, Filozofski seminar teološke fakultete v Ljubljani [račun], 12. junija 1923; 22. decembra 1924; 29. julija 1925; 21 . novembra 1926; 7. avgusta 1930; 19. januarja 1928; 27. junija 1929 [sodobna dela]).

7 Francoska revija Revue Thomiste je izhajala od leta 1893 v Toulousu. Belgijska Revue Neo-scolastique de philosophie je izhajala od leta 1894 v Leuvenu. Divus Thomas (pod tem imenom od 1914) so od 1922 urejali dominikanci v Fribourgu. Revija Philosophisches Jahrbuch je izhajala v Freiburgu in Münchnu od leta 1888. 


\section{Sklep}

Dr. Aleš Ušeničnik spada med najpomembnejše slovenske filozofe v prvi polovici 20. stoletja. Učiteljskemu delu na ljubljanskem bogoslovnem učilišču in na Teološki fakulteti Univerze v Ljubljani je posvetil skoraj pol stoletja. V svoji dolgi akademski karieri je poleg učiteljskega poklica več let opravljal tudi vodstvene službe v upravi ljubljanske Univerze in Teološke fakultete. Ušeničnikove zasluge za napredek (slovenske) znanosti so bile potrjene z raznimi državnimi in cerkvenimi priznanji, ki jih je prejel v času svojega življenja; omenimo prejem reda Svetega Save v letih 1930 in 1938 ter članstvo v imenitni papeški rimski akademiji sv. Tomaža Akvinskega (1937). S svojim delom na področju slovenskega visokega šolstva je zapustil trajen pečat v zgodovini ljubljanske Univerze in univerzitetnega teološkega študija. Bil je eden od utemeljiteljev slovenskega filozofskega izrazoslovja. Ušeničnik je s svojo pisateljsko dejavnostjo, poučevanjem, odgovornimi upravnimi in cerkvenimi službami ter častnimi odlikovanji uspešno potrjeval ugled mlade ljubljanske Univerze in njene članice Teološke fakultete, ki je tako imela v svojem kadru vrhunskega izobraženca, »najučenejšega duhovnika ljubljanske škofije» (Ambrožič 2010, 74). Časopis Slovenec $(12.12 .1937,3)$ je leta 1937 ob ustanovitvi Akademije znanosti in umetnosti v Ljubljani v predstavitvi svojih prvih članov o dr. Alešu Ušeničniku zapisal: »Prof. Aleš Ušeničnik je največji predstavnik krščanske filozofije med Slovenci, odličen polemik in publicist, ki ob vsaki dvomljivi stvari skuša razjasniti položaj s svojo avtoritativno besedo, ter izvrsten metodolog in vzgojitelj slovenskega bogoslovskega naraščaja«. Zdi se, da izbrane besede zrcalijo temeljne strokovne kvalitete dr. Ušeničnika, ki smo jih skušali predstaviti tudi v našem prispevku.

\section{Kratice}

AKBF - Arhiv Katoličkog bogoslovnog fakulteta u Zagrebu.

ATF - Arhiv Teološke fakultete v Ljubljani.

NŠAL - Nadškofijski arhiv Ljubljana.

ZAMU - Zgodovinski arhiv in muzej Univerze v Ljubljani.

\section{Reference}

\section{Arhivski viri}

AKBF, Spisi 1919, št. 97 (98), Strokovna kvalifikacija vseučiliških profesorjev, 1919.

ATF, fascikel 36 (Spisi 1919-1923), Poročilo rednega profesorja dr. Aleša Ušeničnika za študijsko leto 1921/22, 19. junija 1922.

- - -, fascikel 36 (Spisi 1919-1923), Poročilo red. prof. filozofije na teološki fak. dr. Al. Ušeničnika za štud. I. 1922/23, 30. junija 1923.
- - , fascikel 37 (Spisi 1924-1927), Poročilo prof. dr. Al. Ušeničnika v štud. I. 1926/27.

- - -, fascikel 37 (Spisi 1924-1927), Stroke in nastavniki na Teološki fakulteti, I. 1926-27.

- - -, fascikel 39 (Spisi 1928-1931), Poročilo dr. Al. Ušeničnik-a, red. prof. za krščansko filozofijo v štud. I. 1927/28, 21. junija 1928.

- - - fascikel 39 (Spisi 1928-1931), Letno poročilo red. prof. dr. Ušeničnika Aleša o štud. I. 1928/29, 27. junija 1929. 
- - -, fascikel 39 (Spisi 1928-1931), Poročilo o filozofskem seminarju teološke fakultete 1929/30, 1. junija 1930.

- - -, fascikel 39 (Spisi 1928-1931), Poročilo o filozofskem seminarju teološke fakultete 1930/31, 28. junija 1931.

NŠAL, Zapuščine, fascikel 55 (Ušeničnik A.), Filozofski seminar teološke fakultete v Ljubljani [račun], 13. novembra 1922; 16. junija 1924; 24. septembra 1928; 31. oktobra 1928; 27. junija 1929; 25. aprila 1930 idr. [revije].

- - - Zapuščine, fascikel 55 (Ušeničnik A.), Filozofski seminar teološke fakultete v Ljubljani [račun], 22. decembra 1924; 1. septembra 1931; 16. januarja 1925; 29. marca 1926 [zgodovina filozofije].

- - - Zapuščine, fascikel 55 (Ušeničnik A.), Filozofski seminar teološke fakultete v Ljubljani [račun], 12. junija 1923; 22. decembra 1924; 29. julija 1925; 21. novembra 1926; 7. avgusta 1930; 19. januarja 1928; 27. junija 1929 [sodobna dela].

- - -, Spisi V., fascikel 276 (Teološka fakulteta), mapa 1938, Tvarina predelana iz filozofije [dr. Ušeničnik Aleš], 6. junija 1938.

- - -, Spisi V., fascikel 276 (Teološka fakulteta), mapa 1938, Seminarium philosophicum [dr. Ušeničnik Aleš], 6. junija 1938.

ZAMU, Seznam predavanj na univerzi v Ljubljani 1932-1944.

ZAMU IV - 69, personalna mapa Ušeničnik Aleš, Maturitetna svedočba, 1888.

- - , personalna mapa Ušeničnik Aleš, Doktorska diploma iz filozofije, 1891.

- - - personalna mapa Ušeničnik Aleš, Doktorska diploma iz bogoslovja, 1895.

- - -, personalna mapa Ušeničnik Aleš, Imenovanje Aleša Ušeničnika na mesto kaplana v Stari Loki, 1895.

- - -, personalna mapa Ušeničnik Aleš, Imenovanje Aleša Ušeničnika na mesto stolnega vikarja v Ljubljani, 1896.

- - -, personalna mapa Ušeničnik Aleš, Imenovanje Aleša Ušeničnika na mesto suplenta na škofijskem bogoslovnem učilišču v Ljubljani, 1897.

- - -, personalna mapa Ušeničnik Aleš, Imenovanje Aleša Ušeničnika na mesto rednega profesorja na škofijskem bogoslovnem učilišču v Ljubljani, 1900.

- - -, personalna mapa Ušeničnik Aleš, PrestoIonaslednikovo imenovanje Aleša Ušeničnika na mesto rednega profesorja na Teološki fakulteti Univerze v Ljubljani, 1919.

- - -, personalna mapa Ušeničnik Aleš, Kraljevo imenovanje Aleša Ušeničnika za rednega profesorja 2. skupine 1. kategorije, 1926.

- - , personalna mapa Ušeničnik Aleš, Izpisek iz uslužbenskega lista dr. Aleša Ušeničnika, 8. marca 1938.

\section{Časopisni viri}

Slovenec. 12.12.1937, Prvi slovenski akademiki.

\section{Druge reference}

Ambrožič, Matjaž. 2010. Spomini in semeniška kronika 1941-1944 Ignacija Nadraha. Viri (št. 30). Ljubljana: Arhivsko društvo Slovenije.

Bobič, Pavlina. 2011. Jakob Missia. V: Med domom in svetom, 149-170. Življenje in dela 8; Biografske in bibliografske študije 5 . Ur. Igor Grdina. Ljubljana: ZRC SAZU.

Debeljak, Majda. 2018. Na poti z rimskima profesorjema. V: Iskalca resnice: Aleš Ušeničnik in njegov brat Franc, 32-45. Ur. Majda Debeljak. Poljane nad Škofjo Loko: Kulturno društvo dr. Ivan Tavčar Poljane; Ljubljana: Salve.

Juhant, Janez. 1990. Katedra za filozofijo. Bogoslovni vestnik 50 , št. 1-2:46-53.

Kolar, Bogdan. 2009. Delovanje Teološke fakultete med letoma 1919 in 1952. V: 90 let Teološke fakultete v Ljubljani, 58-75. Ur. Bogdan Kolar. Ljubljana: Teološka fakulteta Univerze v Ljubljani.

Lampe, Evgen. 1910. Dr. Aleš Ušeničnik: Sociologija. Dom in svet 23, št. 6:283-284.

Miklavčič, Maks, in Marijan Smolik. 1969. Teološka fakulteta. V: Petdeset let slovenske univerze v Ljubljani: 1919-1969, 567-573. Ur. Roman Modic. Ljubljana: Univerza v Ljubljani.

Petkovšek, Robert. 2008. Novotomizem na Slovenskem v službi kulture resnice. Tretji dan 37, št. 9-10:37-49.

Pirc, Jožko. 1986. Aleš Ušeničnik in znamenja časov: katoliško gibanje na Slovenskem od konca 19. do srede 20. stoletja. Ljubljana: Družina.

Polec, Janko. 1929. Ljubljansko višje šolstvo v preteklosti in borba za slovensko univerzo. V: Zgodovina slovenske univerze v Ljubljani do leta 1929 1929, 1-229.

Strle, Anton. 1968. Ob stoletnici rojstva doktorja Aleša Ušeničnika. Bogoslovni vestnik 28, št. 3-4:170-211. 